\title{
Reactivation of latent viruses after treatment with biological therapies
}

\author{
This article was published in the following Dove Press journal: \\ Virus Adaptation and Treatment \\ 20 June 2014 \\ Number of times this article has been viewed
}

\author{
Anil Kumar Asthana' \\ John Samuel Lubel ${ }^{2,3}$ \\ 'Department of Gastroenterology, \\ The Alfred Hospital, Melbourne, \\ ${ }^{2}$ Department of Gastroenterology and \\ Hepatology, Eastern Health, ${ }^{3}$ Eastern \\ Health Clinical School, Monash \\ University, Melbourne, VIC, Australia
}

\begin{abstract}
Biological therapies are used extensively for malignant (eg, lymphoma) and autoimmune (eg, rheumatoid arthritis) conditions. These agents include anti-tumor necrosis factor antagonists, such as infliximab, and B-cell-depleting therapies, such as rituximab. In the past decade, there has been an explosion in the types and numbers of agents being used. One of the known risks with these agents is infection. In particular, there is increasing awareness regarding latent virus reactivation. This occurs when a latent virus is reactivated into its active replicative phase as a result of an internal or external trigger, such as immunosuppression. It is challenging, however, to quantitatively attribute the risk of reactivation to biological therapy alone because the underlying malignant or autoimmune condition could also be a contributing factor. There is well documented evidence regarding the reactivation of viruses such as hepatitis $\mathrm{B}$ virus and cytomegalovirus with drugs such as rituximab. Long-term data are lacking; such data are essential to guide risk stratification and chemoprophylaxis. Universally accepted viral screening guidelines prior to commencement of immunosuppression are lacking. As an example, the US Centers for Disease Control and Prevention have published recommendations regarding hepatitis B virus screening prior to commencing immunosuppression, but this action has not translated into universally accepted guidelines. Some of the other relevant viruses involved include cytomegalovirus, hepatitis C virus, varicella zoster virus, Epstein-Barr virus, and other members of the herpes family. This article reviews the current literature on the risk of latent viral reactivation with biological therapy, such as anti-tumor necrosis factor and anti-B-cell drugs, with an emphasis on autoimmune conditions.
\end{abstract}

Keywords: latent viruses, autoimmune conditions, biological therapies, reactivation

\section{Introduction}

Biological therapies have become an important class of drugs for the treatment of autoimmune conditions and malignancies. ${ }^{1}$ A broad range of indications exist for their use, including management of autoimmune conditions, malignancies, infectious diseases, organ transplantation, and cardiovascular conditions. ${ }^{2}$ A well recognized complication of this class of drugs is reactivation of pathogenic viruses that may have remained latent in the host following primary infection. ${ }^{3}$ Reactivation occurs when latent viruses switch to a lytic phase of replication. ${ }^{4}$ This process may be triggered by a combination of external or internal stimuli; in the case of biologic therapy, it occurs as a result of immunosuppression.

The immune system, comprising innate and humoral components, can be activated by inflammation, infection, and malignancy. Biologic agents target chemical signals of the immune system in an attempt to halt the ongoing immune response. Examples include
Correspondence: Anil Kumar Asthana Department of Gastroenterology, The Alfred Hospital, 55 Commercial Road, Melbourne, VIC 3004, Australia

Tel +6I 390762000

Email dranilasthana@gmail.com
Virus Adaptation and Treatment 2014:6 I-10

Dovepress

http://dx.doi.org/| 0.21 47/VAAT.S64290 (c) (1) (5) 2014 Asthana and Lubel. This work is published by Dove Medical Press Limited, and licensed under Creative Commons Attribution - Non Commercial (unported, v3.0) BY LC License. The full terms of the License are available at http://creativecommons.org/licenses/by-nc/3.0/. Non-commercial uses of the work are permitted without any further pernision how to request permission may be found at: http://www.dovepress.com/permissions.php 
cytokines such as tumor necrosis factor-alpha (TNF $\alpha$ ), B-cells, and costimulation molecules. In this review, we limit our discussion to latent viral reactivation with the use of monoclonal antibodies. Emphasis will be on the application to autoimmune conditions with references to malignancies.

\section{Literature search}

A comprehensive literature search was conducted using the PubMed database to identify publications written in English during the period January 1990 to February 2014. We matched the terms: "monoclonal antibodies", "biologic therapy", "biologics", "tumor necrosis factor antagonists", "tumor necrosis factor blockade", "tumor necrosis factor inhibitors", "B-cell depletion", "rituximab", "infliximab", "adalimumab", "alemtuzumab", "etanercept", and "abatacept" with the terms "serious infections", "virus infections", "viral infection", "viral reactivation", "latent viral reactivation", "herpes virus", "autoimmune diseases", “autoimmunity”, "hepatitis B virus", "hepatitis B virus reactivation", "varicella zoster virus", "cytomegalovirus", "JC virus", and "opportunistic infections". We included review articles, randomized controlled trials, and case series. Biologic agents, not available for clinical use at present, were excluded from the search criteria.

\section{Use of monoclonal antibodies in autoimmune diseases \\ Tumor necrosis factor antagonists}

Biologic therapies have more specific biological targets than conventional therapies. ${ }^{5}$ The biological therapeutic era essentially arose as a result of hybridoma technology to generate mouse monoclonal antibodies in 1975.6 This technology involves fusing specific antibody-producing B-lymphocytes with a tumor in order to generate a specific monoclonal antibody. ${ }^{6}$ The US Food and Drug Administration approved the first of these agents (muromonab) for use in humans in 1986. Muromonab (OKT3) was the first monoclonal antibody used to block T-cell function and prevent acute rejection post-transplantation. ${ }^{5}$ The initial drugs developed were highly antigenic to humans because the antibodies were entirely composed of mouse proteins. The immune system subsequently produced antimurine protein antibodies, which neutralized the beneficial effects of the monoclonal antibody. Advances in molecular techniques allowed alterations in genetic sequences, leading to development of the first chimeric murine-human products, such as infliximab, followed by humanized antibodies, such as daclizumab, and eventually to human monoclonal antibodies, such as adalimumab. ${ }^{7}$
Cytokines are polypeptides that have a crucial role in mediating inflammation and immunity. ${ }^{8}$ They play an important homeostatic role in the complex interactions between leukocytes, endothelial cells, and the coagulation-fibrinolytic system; all of which are involved in inflammation. ${ }^{8}$ The main targets for monoclonal antibodies include inflammatory cytokines and B-cells, both of which form essential elements of the inflammatory process. The main cytokine targets in the biological therapy industry include TNF $\alpha$, interleukin (IL)-1, and IL-6. B-cell depletion entails targeting CD-20, CD-22, and CD-52 antigens. In all cases, immunogenicity of the protein preparations can be problematic and will be discussed later in this section.

Infliximab, a chimeric antibody with mouse and human domains, was the first monoclonal antibody used for inflammatory bowel disease and gained approval from the US Food and Drug Administration in 1998. ${ }^{9}$ This agent binds to both soluble and transmembrane/receptor-bound forms of TNF $\alpha$, preventing receptor binding and thus neutralizing the biological activity of TNF $\alpha$. With improved antibody biotechnology, subsequent TNF $\alpha$ antagonists with an increased "human" protein component have been developed, thereby addressing the issue of immunogenicity. ${ }^{1}$ Adalimumab is a fully humanized antibody, and certolizumab is again a fully humanized antibody with a PEGylated component, which results in a prolonged half-life. Golimumab is the latest TNF $\alpha$ antagonist, and is a fully human immunoglobulin (Ig)G1 TNF-specific antibody acting on both soluble and membrane-bound TNF $\alpha .{ }^{10}$ The latter three anti-TNF agents are also indicated for use in rheumatologic conditions, such as rheumatoid arthritis. PEGylation of certolizumab extends the half-life of the antibody, and cytotoxicity is also reduced as a result of the missing Fc fragment. ${ }^{11}$

Immunogenicity is the process by which monoclonal antibody proteins provoke antibody formation. ${ }^{12}$ It occurs due to the immune system detecting differences between native and foreign proteins, ${ }^{13}$ and results in a significant proportion of patients undergoing a loss of therapeutic response over time and consequently disease relapse. ${ }^{14}$ These antibodies can either bind or neutralize the monoclonal antibody, leading to altered pharmacokinetics or decreased efficacy of the drug. ${ }^{15}$ This is more relevant with the older generation monoclonal antibodies, such as infliximab (containing a variable murine region, thought to be the antigenic component), but may still occur with the newer generation agents, such as golimumab. ${ }^{16}$ Comedication with immunosuppressive agents such as methotrexate reduces the incidence of antibody formation. ${ }^{14}$ It has been confirmed (in clinical studies) 
that medications such as methotrexate extend the life-span of the monoclonal antibody by reducing anti-drug antibody formation. ${ }^{14}$ As mentioned above, immunogenicity can still occur with the humanized monoclonal antibodies, such as adalimumab. Bartelds et al designed a study to evaluate the incidence of antibody formation against adalimumab and its association with serum adalimumab concentrations as well as clinical response. ${ }^{17}$ Anti-adalimumab antibodies were detected in $17 \%$ of patients during 28 weeks of treatment; those patients who had antibodies present had a worse clinical outcome compared with those without antibodies $(P=0.0001) .{ }^{17}$ Further, patients who were on concomitant methotrexate had a lower incidence of anti-drug antibodies (52\% versus $84 \%, P=0.003) .{ }^{17}$

Infliximab was initially used for Crohn's disease but its use has now been extended to ulcerative colitis, rheumatoid arthritis, ankylosing spondylitis, and psoriatic arthritis. Adalimumab was initially approved for rheumatoid arthritis but is now used for ankylosing spondylitis, Crohn's disease, systemic juvenile idiopathic arthritis, and psoriasis. ${ }^{18}$ Etanercept (human dimeric fusion protein), another TNFo antagonist, is indicated in rheumatologic conditions, such as rheumatoid arthritis, juvenile idiopathic arthritis, psoriatic arthritis, and ankylosing spondylitis. ${ }^{19}$ Certolizumab has been approved for active rheumatoid arthritis whilst golimumab has been approved for rheumatoid arthritis, ankylosing spondylitis, and psoriatic arthritis. ${ }^{20}$

\section{Other cytokine inhibitors}

IL-6 and IL-1 induce the production of acute phase reactants and are well known mediators of fever. This stimulates the liver to produce peptides such as C-reactive protein and serum amyloid protein A during the inflammatory process. In addition to inflammation, IL-6 impacts other systems, including bone metabolism, skeletal muscle physiology, and the endocrine system. Tocilizumab is an IL-6 receptor blocker used for rheumatoid arthritis, systemic juvenile idiopathic arthritis, and Castleman's disease. ${ }^{21}$

IL-1 is another cytokine target, and examples of associated monoclonal antibodies include anakinra and rilonacept. ${ }^{7}$ Indications for the former include rheumatoid arthritis and for the latter cryopyrin-associated periodic syndromes.

\section{B-cell depletion therapies}

B-cells have an integral role in autoimmune conditions, some of which include costimulation of T-lymphocytes, antibody production, and proinflammatory cytokine production. Antibody production by B-cells is a normal physiological process occurring after infection. In addition to this function, B-cells have a crucial role as antigen-presenting cells. Therapeutic monoclonal antibodies bind to cell surface antigens, mainly CD 20, 22, and 52, ${ }^{1}$ causing depletion of these antibody-producing B-cells. Rituximab is a human CD20-specific chimeric monoclonal antibody targeting both naïve, mature, and memory T-cells. The main indications for use of rituximab include lymphoma and other autoimmune conditions such as active rheumatic arthritis that may have failed conventional disease-modifying medications and other TNF $\alpha$ antagonists. Off-label indications include systemic lupus erythematosus and Castleman's disease. ${ }^{21}$

Epratuzumab is an IgG1 monoclonal antibody directed against the CD22 surface antigen. The mechanism of action is through inhibition of the $\mathrm{B}$-cell receptor complex, thus reducing the cell's life-span. ${ }^{22}$ Alemtuzumab, a recombinant humanized $\mathrm{IgG} 1$, is a monoclonal antibody directed against the surface antigen CD52. ${ }^{23}$ In addition to its application in cancers, this monoclonal antibody is used in autoimmune conditions such as multiple sclerosis. ${ }^{1}$

\section{Viral reactivation}

Viral replication is a complex process that relies significantly on the host cell. During the "lytic phase"4 the replicated viral genome (RNA or DNA) is released from the host cell surrounded by a protein shell which together form the virion. This stage of the viral life cycle is called the lytic phase because virion release from the host cell results in cell lysis. The "latent phase", as the term suggests, is the period during which time the virus lays dormant.

More than $90 \%$ of the adult population has been exposed to the herpes virus family consisting of cytomegalovirus (CMV), Epstein-Barr virus (EBV), varicella zoster virus (VZV), and herpes simplex virus (HSV). Following primary infection, these viruses can reside in the host in the latent phase of replication. VZV and HSV generally remain dormant in the neural sensory ganglia whilst CMV and EBV reside in hematopoietic cells. ${ }^{26}$ The polyomaviruses (John Cunningham [ $\mathrm{JC}]$ and $\mathrm{BK}$ viruses) and adenovirus are also known to enter the latent phase of replication. Persistent infection occurs when the virus is not eliminated following primary infection and continues to replicate at a low level without causing significant host cell damage, eg, with hepatitis B virus (HBV). ${ }^{4}$ Therefore, reactivation occurs when the virus switches from the latent phase to the lytic phase during which time the genome is transcribed and translated into proteins. For this to happen, a stimulating trigger needs to be present, such as immunosuppression. Please refer to 
Table 1 for a summary of biologic agents and their associated viral reactivations.

The remainder of this review concentrates on the common latent viruses that may reactivate with use of monoclonal antibodies. It is difficult to attribute the increased risk of latent viral reactivation to these drugs alone because the underlying autoimmune condition may also contribute to the process of reactivation and this is difficult to measure or quantify. Despite this ongoing discussion, we present evidence that supports the role of monoclonal antibodies contributing to viral reactivation.

\section{Hepatitis B virus}

$\mathrm{HBV}$ is an example of a virus that demonstrates features of persistent infection. Recently, there has been increasing awareness of reactivation with immunosuppression. It is well known that HBV can be reactivated with high-dose steroids and biological agents, such as rituximab. ${ }^{27}$ This has also been well documented in the setting of stem cell and organ transplantation. ${ }^{28}$

There have been many reports of the use of TNF inhibitors in HBV-positive patients. A variety of outcomes have been described, ranging from viral clearance to fatal hepatitis. ${ }^{26}$ Patients on anti-TNF medications who did not receive antiviral therapy concurrently were found to have a higher concentration of aminotransferases and HBV loads, and many developed hepatic dysfunction. ${ }^{26}$ A salient study by Esteve et al reviewed the HBV status and outcome in 80 patients with Crohn's disease requiring infliximab infusions. ${ }^{29}$ Three patients with chronic HBV were identified, one of whom suffered a severe viral reactivation and another patient died as a result of reactivation. This was one of the first papers to advocate HBV screening prior to infliximab treatment, with initiation of appropriate chemoprophylaxis in those at risk of reactivation. ${ }^{29}$ Shale et al found the higher risk agents associated with $\mathrm{HBV}$ reactivation to be infliximab and adalimumab as opposed to etanercept. ${ }^{26}$ This would certainly have more implications for clinicians managing inflammatory bowel disease, in which these two biological medications are the agents of choice. The time interval between commencing anti-TNF agents and HBV reactivation varies significantly. ${ }^{26}$ In the majority of cases of $\mathrm{HBV}$ reactivation induced by anti-TNF medications, the patients were hepatitis B surface antigen (HBsAg)-positive. Lamivudine prophylaxis reduces reactivation in patients with $\mathrm{HBV}$ infection concurrently on anti-TNF agents. ${ }^{30}$ In 2008, the Centers for Disease Control and Prevention published recommendations for HBV screening (with HbsAg, hepatitis B surface antibody titer, and hepatitis B core antibody serology) in all patients receiving immunosuppressive agents. This position has not been accepted globally, with some organizations such as the American Society of Clinical Oncology challenging the necessity for testing for occult and past HBV infection in patients receiving less potent immunosuppressive therapies. Cases of HBV reactivation in patients on anti-TNF agents with occult HBV infection (HbsAg-negative but detectable viral load) have been reported. Similarly, patients with past HBV exposure (HbsAg-negative and hepatitis B core antibody-positive with undetectable viral load) are also at risk of viral reactivation. ${ }^{31}$ One possible pragmatic approach would be to stratify the risk of past HBV infection by considering patient demographic characteristics (eg, patient ethnicity) prior to deciding whether the full HBV serology panel (as above) is required prior to initiating anti-TNF therapy. As a minimum, all patients should have HBsAg and hepatitis B surface antibody titers checked prior to commencing anti-TNF treatment. ${ }^{26}$

Rituximab is known to cause HBV reactivation in patients who are HbsAg-positive as well as in those with past HBV infection. ${ }^{32}$ In addition to malignancies, rituximab is indicated

Table I Summary of common monoclonal antibodies used in autoimmune conditions

\begin{tabular}{lllll}
\hline Drug & Drug type & Target & Indications & Viruses reactivated \\
\hline Infliximab $^{24}$ & Chimeric (human-murine) & $\mathrm{TNF} \alpha$ & $\mathrm{CD}$, UC, RA, AS, PA & HBV, CMV \\
Etanercept $^{25}$ & Human dimeric fusion protein & $\mathrm{TNF} \alpha$ & $\mathrm{RA}, \mathrm{AS}, \mathrm{PA}$, JIA & VZV \\
Adalimumab $^{26}$ & Human antibody & $\mathrm{TNF} \alpha$ & $\mathrm{CD}, \mathrm{RA}, \mathrm{AS}, \mathrm{PA}$, JIA & $\mathrm{CMV}, \mathrm{VZV}$ \\
Certolizumab $^{1}$ & Humanized antibody & $\mathrm{TNF} \alpha$ & $\mathrm{CD}$ & Unspecified \\
Rituximab $^{26}$ & Chimeric (human-murine) & $\mathrm{CD} 20$ & $\mathrm{NHL}, \mathrm{RA}$ & $\mathrm{HBV}, \mathrm{VZV}, \mathrm{HSV}, \mathrm{CMV}, \mathrm{PML}$ \\
Alemtuzumab $^{7}$ & Humanized antibody & $\mathrm{CD} 52$ & $\mathrm{MS}, \mathrm{CLL}, \mathrm{NHL}$ & $\mathrm{VMV}, \mathrm{HZH}, \mathrm{VZV}$ \\
Anakinra $^{7}$ & Nonglycosated IL-IR & $\mathrm{IL}-$ I receptor $^{7}$ & $\mathrm{RA}$ & Unspecified \\
Abatacept $^{7}$ & Fusion protein & T-cell costimulation inhibitor & RA, JIA & HSV, VZV \\
\hline
\end{tabular}

Abbreviations: CMV, cytomegalovirus; CD, Crohn's disease; RA, rheumatoid arthritis; PA, psoriatic arthritis; JIA, juvenile idiopathic arthritis; UC, ulcerative colitis; AS, ankylosing spondylitis; MS, multiple sclerosis; CLL, chronic lymphocytic leukemia; NHL, non-Hodgkin's lymphoma; IL, interleukin; PML, progressive multifocal leukoencephalopathy; VZV, varicella zoster virus; VMV, variola minor virus; HBV, hepatitis B virus; HZH, herpes zoster virus; HSV, herpes simplex virus; TNF , tumor necrosis factor alpha; IL-IR, IL-I receptor. 
in rheumatoid arthritis refractory to anti-TNF medications. Other off-label uses include cryoglobulinemia and systemic lupus erythematosus. ${ }^{25}$ Rituximab is a potent immunosuppressant that diminishes the number of B-cells as well as causing cellular dysfunction, hypogammaglobulinemia, and an increased incidence of neutropenia. ${ }^{33}$ Some of these mechanisms may explain the contribution of rituximab to HBV reactivation. Rates of reactivation have been reported in the range of $25 \%-39 \%$, with mortality rates approaching $50 \%$ in some reports. ${ }^{25}$ Rituximab, along with intensive chemotherapy, has also been shown to increase the risk of $\mathrm{HBV}$ reactivation in patients with past exposure to $\mathrm{HBV}$ (HBsAg-negative and hepatitis B core antibody-positive). ${ }^{34}$

The precise magnitude of the increased risk of HBV reactivation with rituximab is unclear; there is an apparent additive effect when combined with cytotoxic chemotherapy regimens, eg, CHOP (cyclophosphamide, hydroxydaunorubicin, vincristine, and prednisone). ${ }^{33}$ Yeo et al designed a study to compare the HBV reactivation rate in patients on chemotherapy without rituximab with those on chemotherapy with rituximab. ${ }^{35}$ Of the initial 104 patients with diffuse large B-cell lymphoma recruited, 80 were $\mathrm{HbsAg-negative.} \mathrm{Of} \mathrm{these} 80$ patients, 25 were treated with CHOP-containing chemotherapy and none had HBV reactivation. Twenty-one patients were treated with rituximab and CHOP and five developed HBV reactivation, with one patient dying due to hepatic failure $(P=0.0148) .{ }^{35}$ This reinforces the clinical suspicion that rituximab therapy represents a high risk for $\mathrm{HBV}$ reactivation in patients with serologic evidence of past HBV infection. For this reason, screening for $\mathrm{HBV}$ is advisable before use of rituximab. ${ }^{27}$ Please refer to Table 2 for a summary of the main studies involved with hepatitis $\mathrm{B}$ virus reactivation with biologic therapy.

\section{Hepatitis C virus}

There is no confirmatory evidence to suggest that TNF antagonists increase the risk of hepatitis $\mathrm{C}$ virus (HCV) reactivation. Studies have shown that levels of TNF are elevated in $\mathrm{HCV}$-positive patients, but the precise impact on the clinical course of this disease remains uncertain. ${ }^{36}$ TNF $\alpha$ is known to influence HCV clearance and hepatitis progression. ${ }^{37}$ Prescribing etanercept as adjuvant therapy for 24 weeks with interferon and ribavarin has been shown to improve the virologic response in patients with $\mathrm{HCV}$ and to decrease the incidence of adverse effects associated with interferon or ribavarin. ${ }^{38}$ Thus, overall, the literature suggests that there is no known detrimental effect of giving TNF antagonists in HCV-positive patients. The longterm effects of these medications in HCV-positive patients are unknown and warrant further longitudinal studies.

The evidence for rituximab and its impact on HCV is somewhat varied. This biological therapy is used predominantly for HCV-related vasculitis. A study by Saadoun et al showed that when rituximab was combined with PEGylated-interferon and ribavarin, it was a safe treatment option with no adverse impact on HCV RNA and did not lead to clinical deterioration. ${ }^{39}$ A Japanese study monitored five HCV-positive patients with B-cell non-Hodgkin's lymphoma undergoing treatment with R-CHOP (rituximab + CHOP). ${ }^{40}$ This treatment regimen was associated with elevated HCV RNA levels, but not liver dysfunction. The same group, 2 years later, published a multicenter, retrospective study, ${ }^{41}$ in which $\mathrm{R}-\mathrm{CHOP}$ in $\mathrm{HCV}$-positive patients was again associated with increased HCV RNA levels $(P=0.06) ; 27 \%$ of patients who received $\mathrm{R}-\mathrm{CHOP}$ had evidence of severe hepatic toxicity compared with

Table 2 Studies of high-risk viral reactivation with monoclonal antibody therapy

\begin{tabular}{|c|c|c|c|c|c|c|c|}
\hline Reference & Year & Country & $\begin{array}{l}\text { Number } \\
\text { studied }\end{array}$ & $\begin{array}{l}\text { Monoclonal } \\
\text { antibodies involved }\end{array}$ & Design & $\begin{array}{l}\text { Virus } \\
\text { involved }\end{array}$ & Reactivation \\
\hline Roux et $\mathrm{al}^{30}$ & 2006 & France & 6 & Anti-TNF & Retrospective study & HBV & Negative \\
\hline Esteve et $\mathrm{al}^{29}$ & 2004 & Spain & 3 & Anti-TNF & Prospective study & HBV & Positive \\
\hline Aksoy et $\mathrm{al}^{47}$ & 2007 & Turkey & 64 & B-cell depletion & Case review & HBV, CMV & Positive \\
\hline Wendling et $\mathrm{al}^{44}$ & 2008 & France & 9 & Anti-TNF & Retrospective study & VZV & Positive \\
\hline D'Ovidio et al $^{46}$ & 2008 & Italy & 11 & Anti-TNF & Prospective study & CMV & Negative \\
\hline Fukushima et $\mathrm{al}^{34}$ & 2009 & Spain & 48 & B-cell depletion & $\begin{array}{l}\text { Retrospective and } \\
\text { prospective study }\end{array}$ & HBV & Positive \\
\hline Loras et $\mathrm{al}^{67}$ & 2010 & Spain & 162 & Anti-TNF & Retrospective study & HBV & Positive \\
\hline Cassano et $\mathrm{a}^{68}$ & 2011 & Italy & 62 & Anti-TNF & Retrospective study & HBV & Negative \\
\hline Tamori et al ${ }^{69}$ & 2011 & Japan & 50 & $\begin{array}{l}\text { Disease-modifying } \\
\text { drugs and anti-TNF }\end{array}$ & Prospective study & HBV & Positive \\
\hline Dong et $\mathrm{al}^{70}$ & 2013 & $\begin{array}{l}\text { People's } \\
\text { Republic of } \\
\text { China }\end{array}$ & 971 & B-cell depletion & $\begin{array}{l}\text { Systematic review } \\
\text { and meta-analysis }\end{array}$ & HBV & Positive \\
\hline
\end{tabular}

Abbreviations: TNF, tumor necrosis factor; HBV, hepatitis B virus; CMV, cytomegalovirus; VZV, varicella zoster virus. 
$3 \%$ in the group that did not receive this immunotherapy (hazards ratio 14.72, 95\% confidence interval 6.37-34.03; $P<0.01){ }^{41}$ Therefore, monitoring of hepatic function and HCV RNA is advisable when prescribing rituximab in this group of patients. ${ }^{25}$

\section{Herpes viruses}

As mentioned previously, the majority of the population has been exposed to the viruses of this family, ie, CMV, VZV, HSV-1, and EBV. Reactivation of these viruses is common in transplant patients as well as other immunosuppressed patients. ${ }^{42}$

\section{Varicella zoster virus}

Reactivation of VZV is recognized to occur with anti-TNF therapy. ${ }^{43,44} \mathrm{VZV}$ can also reactivate once anti-TNF therapy is recommenced after a period of cessation. ${ }^{44}$ Wendling et al conducted a retrospective review showing that up to $3 \%$ of patients who were receiving anti-TNF therapy underwent reactivation of herpes zoster virus. ${ }^{44}$ Infliximab and adalimumab were often implicated. A prospective cohort study in Germany investigated whether anti-TNF medications, as a group or individually, were related to higher rates of herpes zoster infections. ${ }^{43}$ They studied approximately 5,000 patients and found that treatment with anti-TNF monoclonal antibodies was associated with an increased risk of herpes zoster reactivation. ${ }^{43}$ The risk was doubled with the use of infliximab and adalimumab after adjustment for concomitant use of corticosteroids, with an incidence of 11/1,000 patient-years for herpes zoster with adalimumab and infliximab and 8.9/1,000 patient-years with etanercept. In addition, $18 \%$ of the cases were multidermatomal, 13\% required hospitalization, and 5\% had a recurrence. ${ }^{26}$ It has therefore been suggested that herpes zoster infection in the setting of anti-TNF therapy may be more severe. ${ }^{44,45}$ In the setting of active infection, anti-TNF medications should be stopped until the vesicles resolve and then recommenced in conjunction with antiviral medications. ${ }^{26}$ The immunization status of these patients should be checked and the appropriate vaccinations given prior to commencing anti-TNF since they are live vaccines and should not be given concurrently with anti-TNF therapy.

\section{Cytomegalovirus}

There are considerable data regarding the association of immunosuppression with CMV infection or disease, but less information regarding biological therapy and reactivation of this virus. Even though CMV infection is not an uncommon cause of morbidity and mortality in immunosuppressed patients, eg, post hematopoietic stem cell transplantation, the role of TNF $\alpha$ antagonists in triggering reactivation remains speculative. ${ }^{25}$ D'Ovidio et al set out to answer this question by evaluating the presence and severity of CMV infection in infliximab-treated patients with inflammatory bowel disease. ${ }^{46}$ Eleven patients with ileocolonic or colonic disease and four patients with ulcerative colitis were evaluated for active CMV infection by measurement of serum pp65 antigenemia and measurement of CMV DNA from colonic biopsies. All patients had been treated with infliximab. Nine of the eleven patients were CMV-seropositive and one patient had positive serum pp65 antigenemia. Three patients had CMV DNA positivity on colonic biopsies. Despite these results, active infection did not progress to disease after administration of infliximab. This study concluded that anti-TNF therapy does not impact on the clinical course of CMV infection. ${ }^{46}$ Rituximab in conjunction with cytotoxic chemotherapy has been shown to increase the risk of CMV reactivation. ${ }^{47,48}$ In one retrospective study of patients with non-Hodgkin's lymphoma, the risk of developing CMV infection after hematopoietic stem cell transplantation was higher in the rituximab-treated group than in a group not treated with this biological therapy (17.6\% versus $0 \%, P=0.045$ ).

Alemtuzumab, a humanized anti-CD52 monoclonal antibody, has also been associated with a higher risk of CMV disease in patients with hematologic malignancies, ${ }^{49-51}$ but this has not been studied thoroughly in the setting of autoimmune disease per se.

\section{Epstein-Barr virus}

In over $90 \%$ of the population, EBV causes persistent latent infection of B-lymphocytes. ${ }^{52}$ The potential role of anti-TNF therapy in reactivation is related to the development of EBVrelated lymphoma. Even though it is suspected that there is an overall increase in risk, this has not been supported by substantial evidence. ${ }^{53}$ There have been documented cases of EBV-related lymphoproliferative disorders with the use of anti-TNF therapy. ${ }^{54}$ As the majority of EBV infections result in latent infection, it is presumed that these lymphoproliferative disorders are due to viral reactivation rather than primary infection. Interestingly, regression of lymphoma has been observed following discontinuation of anti-TNF therapy. ${ }^{54}$ Conversely, a study reviewing approximately 6,000 patients on anti-TNF therapy for rheumatoid arthritis found no increased risk of lymphoma with this class of biological therapy. ${ }^{55}$

Following published literature with regard to lymphoproliferative disease, Balandraud et al set out to monitor EBV 
load in rheumatoid arthritis patients on anti-TNF therapy (infliximab or etanercept). ${ }^{56}$ Duration of follow-up ranged from 6 months to 5 years, and there was no significant change in EBV load over time as a consequence of these medications. ${ }^{56}$ It has been documented that a significant risk factor for subsequent development of lymphoma is an EBV load of greater than 1,000 copies $/ 10^{5}$ peripheral blood mononuclear cells. ${ }^{57}$ Lavagna et al studied the effect of infliximab on reactivation of several latent viruses in a Crohn's disease population, ${ }^{58}$ and did not find that infliximab facilitated EBV replication. Other studies, even though reporting an increased EBV level with the use of infliximab, did not conclude that these levels were high enough to be considered a risk for lymphoproliferative disorders.

\section{Herpes simplex virus}

Despite case reports of herpes viral reactivation, there is no evidence to suggest that anti-TNF therapy is a significant risk factor for HSV reactivation. There have been case reports of HSV esophagitis and herpetic encephalitis in the setting of TNF $\alpha$ antagonists. ${ }^{59}$

\section{Human papillomavirus}

A study of women with inflammatory bowel disease on infliximab as well as other immunosuppressant medication found higher rates of cervical dysplasia secondary to papillomavirus compared with controls (odds ratio 4.5, 0.05\% confidence interval 1.5-12.3). ${ }^{60} \mathrm{~A}$ subsequent study in an inflammatory bowel disease population on immunosuppression including infliximab did not find a statistically significant elevation in risk of cervical cancer and thus papillomavirus. ${ }^{61}$ Despite the above findings, reactivation of papillomavirus with biologic therapy has not been established.

\section{Human herpesvirus- 8}

There has been documentation of human herpesvirus- 8 reactivation in a prospective study of 60 patients with inflammatory bowel disease who were receiving infliximab. ${ }^{25}$ There have not been any further data to substantially support the role of biological therapy in reactivation of this virus.

\section{Polyomavirus}

JC virus is known to cause progressive multifocal leukoencephalopathy, a fatal central nervous system demyelinating disease. This association became well known in patients with multiple sclerosis who had received the integrin inhibitor, natalizumab. ${ }^{62}$ Another biological agent associated with this disease is efalizumab (used for psoriasis). ${ }^{62}$ Fleischmann published a case report of a patient with rheumatoid arthritis on rituximab who developed multifocal leukoencephalopathy. ${ }^{63}$ Other studies have demonstrated the presence of JC virus DNA in the blood whilst on biologic therapy but not fulminant reactivation causing multifocal leukoencephalopathy. ${ }^{64,65}$ Like herpes zoster, JC virus remains in a latent phase and has been found in oligodendrocytes and astrocytes of the human brain; reactivation of the transcriptional process of JC virus may be the initial trigger in the lead-up to multifocal leukoencephalopathy. ${ }^{66}$

\section{Implications for disease management and patient-specific considerations}

In the last 10-15 years there have been dramatic advances in the therapeutic options for autoimmune conditions and malignancies. The current generation of biological therapies are more target-specific, better tolerated, and often more efficacious than the traditional immunosuppressive agents. However, caution needs to be exercised by the clinician, because there are few long-term data regarding the infectious complications using these relatively new therapies. In addition, we are witnessing an exponential increase in both the number of biological agents and also the number of new-target therapies, eg, tofacitinib, which is a Janus kinase inhibitor for ulcerative colitis. ${ }^{71}$ When initiating biological therapy in patients, the clinician should risk-stratify the patient for viral screening. Lifestyle factors, such as intravenous drug use and ethnicity, will assist in determining which viruses to screen for prior to commencement. This is the other future dilemma for the clinician, ie, screening practices prior to instigating biologic therapy. Unfortunately, there are no robust guidelines for viral screening to guide the clinician; the most abundant evidence exists for HBV reactivation following immunosuppression. ${ }^{27}$ Factors to take into consideration during pretherapy viral screening include patient demographics and known risk factors, as well as the current literature on biologic therapy and known associated infectious complications.

\section{Conclusion and future directions}

Latent viral reactivation is a complex process and an increasingly relevant clinical issue with the growing use of biological therapy. Latent viral reactivation occurs following primary viral infection of the host and can be precipitated by internal and external triggers, eg, immunosuppression. The virus transitions from the latent phase to a lytic phase of the viral lifecycle, during which time the genome is transcribed 
and translated into proteins. Much of the current literature is based on early generation biological therapies, and with the advent of newer therapies, it is necessary to collect shortterm and long-term data. HBV reactivation with immunosuppression, as an example, has been extensively studied and it would be helpful to study other viruses in similar depth. Guidelines similar to that for HBV screening are necessary for other relevant viruses, as discussed above, eg, CMV in the setting of biological therapy. This will only be possible upon publication of high quality evidence that is yet awaited. Long-term outcomes of latent viral reactivation with different classes of biological therapy are essential to help with clinical decisions and patient counseling, with informed consent regarding latent viral reactivation prior to starting immunosuppression being paramount. This continues to be a fascinating and evolving area of science that is becoming an increasingly important issue for the clinician.

\section{Disclosure}

The authors report no conflicts of interest in this work.

\section{References}

1. Chan AC, Carter PJ. Therapeutic antibodies for autoimmunity and inflammation. Nat Rev Immunol. 2010;10(5):301-316.

2. Reichert JM. Antibody-based therapeutics to watch in 2011. MAbs. 2011;3(1):76-99.

3. Chakravarty EF. Viral infection and reactivation in autoimmune disease. Arthritis Rheum. 2008;58(10):2949-2957.

4. Traylen CM, Patel HR, Fondaw W, et al. Virus reactivation: a panoramic view in human infections. Future Virol. 2011;6(4):451-463.

5. Gerber DE. Targeted therapies: a new generation of cancer treatments. Am Fam Physician. 2008;77(3):311-319.

6. Kohler G, Milstein C. Continuous cultures of fused cells secreting antibody of predefined specificity. Nature. 1975;256(5517):495-497.

7. Salvana EM, Salata RA. Infectious complications associated with monoclonal antibodies and related small molecules. Clin Microbiol Rev. 2009;22(2):274-290.

8. Grignani G, Maiolo A. Cytokines and hemostasis. Haematologica. 2000;85(9):967-972.

9. Targan SR, Hanauer SB, van Deventer SJ, et al. A short-term study of chimeric monoclonal antibody cA2 to tumor necrosis factor alpha for Crohn's disease. Crohn's Disease cA2 Study Group. $N$ Engl J Med. 1997;337(15):1029-1035.

10. Inman RD, Davis JC Jr, Heijde D, et al. Efficacy and safety of golimumab in patients with ankylosing spondylitis: results of a randomized, double-blind, placebo-controlled, phase III trial. Arthritis Rheum. 2008;58(11):3402-3412.

11. Fleischmann R, Vencovsky J, van Vollenhoven RF, et al. Efficacy and safety of certolizumab pegol monotherapy every 4 weeks in patients with rheumatoid arthritis failing previous disease-modifying antirheumatic therapy: the FAST4WARD study. Ann Rheum Dis. 2009;68(6): 805-811.

12. Harding FA, Stickler MM, Razo J, DuBridge RB. The immunogenicity of humanized and fully human antibodies: residual immunogenicity resides in the CDR regions. MAbs. 2010;2(3):256-265.

13. Schellekens H. Factors influencing the immunogenicity of therapeutic proteins. Nephrol Dial Transplant. 2005;20 Suppl 6:vi3-vi9.
14. Jani M, Barton A, Warren RB, Griffiths CE, Chinoy H. The role of DMARDs in reducing the immunogenicity of TNF inhibitors in chronic inflammatory diseases. Rheumatology. 2014;53(2):213-222.

15. Sethu S, Govindappa K, Alhaidari M, Pirmohamed M, Park K, Sathish J. Immunogenicity to biologics: mechanisms, prediction and reduction. Arch Immunol Ther Exp (Warsz). 2012;60(5):331-344.

16. Zidi I, Bouaziz A, Ben Amor N. Golimumab and immunogenicity? 2010 and beyond. Pharmazie. 2011;66(4):233-243.

17. Bartelds GM, Wijbrandts CA, Nurmohamed MT, et al. Clinical response to adalimumab: relationship to anti-adalimumab antibodies and serum adalimumab concentrations in rheumatoid arthritis. Ann Rheum Dis. 2007;66(7):921-926.

18. Bacquet-Deschryver H, Jouen F, Quillard M, et al. Impact of three anti-TNFalpha biologics on existing and emergent autoimmunity in rheumatoid arthritis and spondylarthropathy patients. J Clin Immunol. 2008;28(5):445-455.

19. Kerensky TA, Gottlieb AB, Yaniv S, Au SC. Etanercept: efficacy and safety for approved indications. Exp Opin Drug Safe. 2012;11(1):121-139.

20. Keystone EC, Genovese MC, Klareskog L, et al. Golimumab, a human antibody to tumour necrosis factor \{alpha $\}$ given by monthly subcutaneous injections, in active rheumatoid arthritis despite methotrexate therapy: the GO-FORWARD Study. Ann Rheum Dis. 2009;68(6):789-796.

21. Rosman Z, Shoenfeld Y, Zandman-Goddard G. Biologic therapy for autoimmune diseases: an update. BMC Med. 2013;11:88.

22. Dorner T, Goldenberg DM. Targeting CD22 as a strategy for treating systemic autoimmune diseases. Ther Clin Risk Manage. 2007;3(5): 953-959.

23. $\mathrm{Hu}$ Y, Turner MJ, Shields J, et al. Investigation of the mechanism of action of alemtuzumab in a human CD52 transgenic mouse model. Immunology. 2009;128(2):260-270.

24. Vassilopoulos D, Calabrese LH. Risks of immunosuppressive therapies including biologic agents in patients with rheumatic diseases and co-existing chronic viral infections. Curr Opin Rheumatol. 2007;19(6): 619-625.

25. Gentile G, Foa R. Viral infections associated with the clinical use of monoclonal antibodies. Clin Microbiol Infect. 2011;17(12):1769-1775.

26. Shale MJ, Seow CH, Coffin CS, Kaplan GG, Panaccione R, Ghosh S. Review article: chronic viral infection in the anti-tumour necrosis factor therapy era in inflammatory bowel disease. Aliment Pharmacol Ther. 2010;31(1):20-34.

27. Lubel JS, Angus PW. Hepatitis B reactivation in patients receiving cytotoxic chemotherapy: diagnosis and management. J Gastroenterol Hepatol. 2010;25(5):864-871.

28. Firpi RJ, Nelson DR. Management of viral hepatitis in hematologic malignancies. Blood Rev. 2008;22(3):117-126.

29. Esteve M, Saro C, Gonzalez-Huix F, Suarez F, Forne M, Viver JM. Chronic hepatitis B reactivation following infliximab therapy in Crohn's disease patients: need for primary prophylaxis. Gut. 2004;53(9): 1363-1365.

30. Roux CH, Brocq O, Breuil V, Albert C, Euller-Ziegler L. Safety of antiTNF-alpha therapy in rheumatoid arthritis and spondylarthropathies with concurrent B or C chronic hepatitis. Rheumatology. 2006;45(10): 1294-1297.

31. Huang YW, Chung RT. Management of hepatitis B reactivation in patients receiving cancer chemotherapy. Therap Adv Gastroenterol. 2012;5(5):359-370.

32. Coiffier B. Hepatitis B virus reactivation in patients receiving chemotherapy for cancer treatment: role of lamivudine prophylaxis. Cancer Invest. 2006;24(5):548-552.

33. Kelesidis T, Daikos G, Boumpas D, Tsiodras S. Does rituximab increase the incidence of infectious complications? A narrative review. Int $J$ Infect Dis. 2011;15(1):e2-e16.

34. Fukushima N, Mizuta T, Tanaka M, et al. Retrospective and prospective studies of hepatitis B virus reactivation in malignant lymphoma with occult HBV carrier. Ann Oncol. 2009;20(12):2013-2017. 
35. Yeo W, Chan TC, Leung NW, et al. Hepatitis B virus reactivation in lymphoma patients with prior resolved hepatitis B undergoing anticancer therapy with or without rituximab. J Clin Oncol. 2009;27(4): 605-611.

36. Raychaudhuri SP, Nguyen CT, Raychaudhuri SK, Gershwin ME. Incidence and nature of infectious disease in patients treated with antiTNF agents. Autoimmun Rev. 2009;9(2):67-81.

37. Ferri C, Govoni M, Calabrese L. The A, B, Cs of viral hepatitis in the biologic era. Curr Opin Rheumatol. 2010;22(4):443-450.

38. Zein NN; Etanercept Study Group. Etanercept as an adjuvant to interferon and ribavirin in treatment-naive patients with chronic hepatitis $\mathrm{C}$ virus infection: a phase 2 randomized, double-blind, placebo-controlled study. J Hepatol. 2005;42(3):315-322.

39. Saadoun D, Resche-Rigon M, Sene D, Perard L, Karras A, Cacoub P. Rituximab combined with Peg-interferon-ribavirin in refractory hepatitis C virus-associated cryoglobulinaemia vasculitis. Ann Rheum Dis. 2008;67(10):1431-1436

40. Ennishi D, Terui Y, Yokoyama M, et al. Monitoring serum hepatitis C virus (HCV) RNA in patients with $\mathrm{HCV}$-infected CD20-positive B-cell lymphoma undergoing rituximab combination chemotherapy. Am J Hematol. 2008;83(1):59-62.

41. Ennishi D, Maeda Y, Niitsu N, et al. Hepatic toxicity and prognosis in hepatitis $\mathrm{C}$ virus-infected patients with diffuse large B-cell lymphoma treated with rituximab-containing chemotherapy regimens: a Japanese multicenter analysis. Blood. 2010;116(24):5119-5125.

42. Masur H, Kaplan JE, Holmes KK; US. Public Health Service; Infectious Diseases Society of America. Guidelines for preventing opportunistic infections among HIV-infected persons-2002. Recommendations of the US. Public Health Service and the Infectious Diseases Society of America. Ann Intern Med. 2002;137(5 Pt 2):435-478.

43. Strangfeld A, Listing J, Herzer P, et al. Risk of herpes zoster in patients with rheumatoid arthritis treated with anti-TNF-alpha agents. JAMA. 2009;301(7):737-744.

44. Wendling D, Streit G, Toussirot E, Prati C. Herpes zoster in patients taking TNFalpha antagonists for chronic inflammatory joint disease. Joint Bone Spine. 2008;75(5):540-543.

45. Becart S, Segaert S. Recurrent varicella in an adult psoriasis patient treated with etanercept. Dermatology. 2008;217(3):260-261.

46. D'Ovidio V, Vernia P, Gentile G, et al. Cytomegalovirus infection in inflammatory bowel disease patients undergoing anti-TNFalpha therapy. J Clin Virol. 2008;43(2):180-183.

47. Aksoy S, Harputluoglu H, Kilickap S, et al. Rituximab-related viral infections in lymphoma patients. Leuk Lymphoma. 2007;48(7):1307-1312.

48. Gentile G. Recent developments in new and old viral infections. Rev Clin Exp Hematol. 2005;9(2):E3.

49. Osterborg A, Karlsson C, Lundin J, Kimby E, Mellstedt H. Strategies in the management of alemtuzumab-related side effects. Semin Oncol. 2006;33(2 Suppl 5):S29-S35.

50. Thursky KA, Worth LJ, Seymour JF, Miles Prince H, Slavin MA. Spectrum of infection, risk and recommendations for prophylaxis and screening among patients with lymphoproliferative disorders treated with alemtuzumab*. Br J Haematol. 2006;132(1):3-12.

51. Vallejo C, Rios E, de la Serna J, et al. Incidence of cytomegalovirus infection and disease in patients with lymphoproliferative disorders treated with alemtuzumab. Exp Rev Hematol. 2011;4(1):9-16.

52. Macsween KF, Crawford DH. Epstein-Barr virus - recent advances. Lancet Infect Dis. 2003;3(3):131-140.

53. Balandraud N, Roudier J, Roudier C. What are the links between EpsteinBarr virus, lymphoma, and tumor necrosis factor antagonism in rheumatoid arthritis? Semin Arthritis Rheum. 2005;(5 Suppl 1):31-33.

54. Brown SL, Greene MH, Gershon SK, Edwards ET, Braun MM. Tumor necrosis factor antagonist therapy and lymphoma development: twentysix cases reported to the Food and Drug Administration. Arthritis Rheum. 2002;46(12):3151-3158.
55. Askling J, Baecklund E, Granath F, et al. Anti-tumour necrosis factor therapy in rheumatoid arthritis and risk of malignant lymphomas: relative risks and time trends in the Swedish Biologics Register. Ann Rheum Dis. 2009;68(5):648-653.

56. Balandraud N, Guis S, Meynard JB, Auger I, Roudier J, Roudier C. Long-term treatment with methotrexate or tumor necrosis factor alpha inhibitors does not increase epstein-barr virus load in patients with rheumatoid arthritis. Arthritis Rheum. 2007;57(5):762-767.

57. Weinstock DM, Ambrossi GG, Brennan C, Kiehn TE, Jakubowski A Preemptive diagnosis and treatment of Epstein-Barr virus-associated post transplant lymphoproliferative disorder after hematopoietic stem cell transplant: an approach in development. Bone Marrow Transplant. 2006;37(6):539-546.

58. Lavagna A, Bergallo M, Daperno M, et al. Infliximab and the risk of latent viruses reactivation in active Crohn's disease. Inflamm Bowel Dis. 2007;13(7):896-902.

59. Bradford RD, Pettit AC, Wright PW, et al. Herpes simplex encephalitis during treatment with tumor necrosis factor-alpha inhibitors. Clin Infect Dis. 2009;49(6):924-927.

60. Kane S, Khatibi B, Reddy D. Higher incidence of abnormal Pap smears in women with inflammatory bowel disease. Am $J$ Gastroenterol. 2008;103(3):631-636.

61. Hutfless S, Fireman B, Kane S, Herrinton LJ. Screening differences and risk of cervical cancer in inflammatory bowel disease. Aliment Pharmacol Ther. 2008;28(5):598-605.

62. Chalkley JJ, Berger JR. Progressive multifocal leukoencephalopathy in multiple sclerosis. Curr Neurol Neurosci Rep. 2013;13(12):408.

63. Fleischmann RM. Progressive multifocal leukoencephalopathy following rituximab treatment in a patient with rheumatoid arthritis. Arthritis Rheum. 2009;60(11):3225-3228.

64. Giannecchini S, Clausi V, Vultaggio A, et al. Assessment of the risk of polyomavirus $\mathrm{JC}$ reactivation in patients with immune-mediated diseases during long-term treatment with infliximab. J Neurovirol. 2012;18(1):55-61.

65. Nardis C, Anzivino E, Bellizzi A, et al. Reactivation of human polyomavirus JC in patients affected by psoriasis vulgaris and psoriatic arthritis and treated with biological drugs: preliminary results. J Cell Physiol. 2012;227(12):3796-3802.

66. Wollebo HS, Safak M, Del Valle L, Khalili K, White MK. Role for tumor necrosis factor-alpha in JC virus reactivation and progressive multifocal leukoencephalopathy. J Neuroimmunol. 2011;233(1-2):46-53.

67. Loras C, Gisbert JP, Minguez M, et al. Liver dysfunction related to hepatitis $\mathrm{B}$ and $\mathrm{C}$ in patients with inflammatory bowel disease treated with immunosuppressive therapy. Gut. 2010;59(10):1340-1346.

68. Cassano N, Mastrandrea V, Principi M, et al. Anti-tumor necrosis factor treatment in occult hepatitis B virus infection: a retrospective analysis of 62 patients with psoriatic disease. J Biol Regul Homeost Agents. 2011;25(2):285-289.

69. Tamori A, Koike T, Goto H, et al. Prospective study of reactivation of hepatitis B virus in patients with rheumatoid arthritis who received immunosuppressive therapy: evaluation of both HBsAg-positive and HBsAg-negative cohorts. J Gastroenterol. 2011;46(4):556-564.

70. Dong HJ, Ni LN, Sheng GF, Song HL, Xu JZ, Ling Y. Risk of hepatitis B virus (HBV) reactivation in non-Hodgkin lymphoma patients receiving rituximab-chemotherapy: a meta-analysis. J Clin Virol. 2013;57(3): 209-214.

71. Sandborn WJ, Ghosh S, Panes J, et al. A Phase 2 study of tofacitinib, an oral janus kinase inhibitor, in patients with Crohn's Disease. Clin Gastroenterol Hepatol. January 27, 2014. [Epub ahead of print.] 
Virus Adaptation and Treatment

Dovepress

\section{Publish your work in this journal}

Virus Adaptation and Treatment is an international, peer-reviewed open access journal focusing on the study of virology, viral adaptation and the development and use of antiviral drugs and vaccines to achieve improved outcomes in infection control and treatment. The journal welcomes original research, basic science, clinical \& epidemiological

studies, reviews \& evaluations, expert opinion and commentary, case reports and extended reports. The manuscript management system is completely online and includes a very quick and fair peer-review system, which is all easy to use. Visit http://www.dovepress.com/ testimonials.php to read real quotes from published authors.

Submit your manuscript here: http://www.dovepress.com/virus-adaptation-and-treatment-journal 